\title{
TOOTH SENSITIVITY AMONG RESIDENTIAL UNIVERSITY STUDENTS IN CHENNAI
}

\author{
GOKUL G ${ }^{1}$, ABILASHA S \\ ${ }^{1}$ Department of Dental Anatomy, Saveetha Dental College, Chennai - 600 077, Tamil Nadu, India. ${ }^{2}$ Department of Oral Pathology, Saveetha \\ Dental College, Chennai - 600 077, Tamil Nadu, India. Email: gokul.guna.1997.g@gmail.com
}

Received: 03 June 2016, Revised and Accepted: 20 June 2016

\section{ABSTRACT}

Objective: To assess the experience of TS of residential university students from different universities in Chennai.

Methods: Students of different colleges were given questionnaires on TS. The answered questionnaires were then analyzed in SPSS online software and the results were found

Results: From the data, it is infered that the knowledge of treatment for TS isn't well-known among students and improper brushing techniques and soft drink consumption are main reasons for TS.

Conclusion: From the data, one can infer that TS has becomeNo quite prevalent in today's society and with less awareness on its treatment. The people should be taught to maintain their oral hygiene, and proper brushing techniques should be taught and diet should be altered according to health. Soft drinks should be avoided to the highest extent and treatment for sensitivity should be taken promptly.

Keywords: Dentin, sensitivity, students.

(C) 2016 The Authors. Published by Innovare Academic Sciences Pvt Ltd. This is an open access article under the CC BY license (http://creativecommons. org/licenses/by/4. 0/) DOI: http://dx.doi.org/10.22159/ajpcr.2016.v9s2.13228

\section{INTRODUCTION}

Tooth sensitivity (TS) or dentine hypersensitivity has been defined as the sudden or transient pain arising from exposed dentine on contact with chemical, thermal, tactile, or osmotic stimuli, which does not as arise due to any dental defect or pathology [1]. Cold and air stimulations are known to be the most common trigger [2,3], which has shown to have a significant potential in evoking dentine sensitivity [4]. This sensitivity can be explained by one of the most accepted theories, which is the hydrodynamic theory which states that the flow of fluid in dentinal tubules trigger receptors within the tooth. It is the most widely accepted theory explaining TS from the other stated theories [5]. Dentine hypersensitivity affects eating, drinking, and breathing. Increased sensitivity hampers the ability to control dental plaque effectively and can thereby disturb the maintenance of one's oral health. Severe hypersensitivity may even result in emotional changes that can alter lifestyle [6]. In general, a slightly higher incidence of dentine hypersensitivity is reported in females [7,8], which was said to reflect their overall health care and better oral hygiene awareness [9]. The reasons for improper care for dentinal sensitivity as the conditions for stimulated, so they develop adaptive behavior of restricting self from stimulants and seldom avoid using the affected side of the mouth $[10,11]$. This survey is done to find the prevalence of TS and the habits and lifestyles of the people affected by dentine hypersensitivity in residential students and thereby provide an insight into the leading causes of TS and thereby provide treatment and help to provide awareness.

\section{METHODS}

The survey was conducted on the residential students of five universities situated in Chennai. The students were randomly asked if they suffered from TS and were given questionnaires which were filled with the consent of the students who suffered from TS. The numbers of students without TS were also noted. These data were then analyzed using SPSS software and put in the form of tables.

\section{RESULTS}

The survey mainly focused on the students suffering from TS and from questioning almost 217 students, 110 students were found to suffer from TS. The following data show the habits and potential causes of dentin hypersensitivity.

\begin{tabular}{lllll}
\hline \multicolumn{4}{l}{ Students with tooth sensitivity } & \\
\hline Valid & Frequency & Percentage & $\begin{array}{l}\text { Valid } \\
\text { percentage }\end{array}$ & $\begin{array}{l}\text { Cumulative } \\
\text { percentage }\end{array}$ \\
\hline Male & 67 & 60.9 & 60.9 & 60.9 \\
Female & 43 & 39.1 & 39.1 & 100.0 \\
Total & 110 & 100.0 & 100.0 & \\
\hline
\end{tabular}

\begin{tabular}{lllll}
\hline \multicolumn{2}{l}{ Stimulus } & & & \\
\hline Valid & Frequency & Percentage & $\begin{array}{l}\text { Valid } \\
\text { percentage }\end{array}$ & $\begin{array}{l}\text { Cumulative } \\
\text { percentage }\end{array}$ \\
\hline Cold & 87 & 79.1 & 79.1 & 79.1 \\
Hot & 5 & 4.5 & 4.5 & 83.6 \\
Both & 18 & 16.4 & 16.4 & 100.0 \\
Total & 110 & 100.0 & 100.0 & \\
\hline
\end{tabular}

\begin{tabular}{|c|c|c|c|c|}
\hline \multicolumn{5}{|c|}{ Avoiding pain } \\
\hline Valid & Frequency & Percentage & $\begin{array}{l}\text { Valid } \\
\text { percentage }\end{array}$ & $\begin{array}{l}\text { Cumulative } \\
\text { percentage }\end{array}$ \\
\hline $\begin{array}{l}\text { Normal } \\
\text { temperature }\end{array}$ & 89 & 80.9 & 80.9 & 80.9 \\
\hline Avoid food & 21 & 19.1 & 19.1 & 100.0 \\
\hline Total & 110 & 100.0 & 100.0 & \\
\hline
\end{tabular}




\begin{tabular}{lllll}
\hline \multicolumn{3}{l}{ Type of tooth brush } & & \\
\hline Valid & Frequency & Percentage & $\begin{array}{l}\text { Valid } \\
\text { percentage }\end{array}$ & $\begin{array}{l}\text { Cumulative } \\
\text { percentage }\end{array}$ \\
\hline Soft & 10 & 9.1 & 9.1 & 9.1 \\
Medium & 68 & 61.8 & 61.8 & 70.9 \\
Hard & 32 & 29.1 & 29.1 & 100.0 \\
Total & 110 & 100.0 & 100.0 & \\
\hline
\end{tabular}

\begin{tabular}{lllll}
\hline \multicolumn{2}{l}{ Force of brushing } & & & \\
\hline Valid & Frequency & Percentage & $\begin{array}{l}\text { Valid } \\
\text { percentage }\end{array}$ & $\begin{array}{l}\text { Cumulative } \\
\text { percentage }\end{array}$ \\
\hline Vigorous & 59 & 53.6 & 53.6 & 53.6 \\
Mild & 44 & 40.0 & 40.0 & 93.6 \\
Soft & 7 & 6.4 & 6.4 & 100.0 \\
Total & 110 & 100.0 & 100.0 & \\
\hline
\end{tabular}

\begin{tabular}{lllll}
\hline \multicolumn{3}{l}{ Frequency of brushing } & & \\
\hline Valid & Frequency & Percentage & $\begin{array}{l}\text { Valid } \\
\text { percentage }\end{array}$ & $\begin{array}{l}\text { Cumulative } \\
\text { percentage }\end{array}$ \\
\hline Once & 92 & 83.6 & 83.6 & 83.6 \\
Twice & 18 & 16.4 & 16.4 & 100.0 \\
Total & 110 & 100.0 & 100.0 & \\
\hline
\end{tabular}

\begin{tabular}{|c|c|c|c|c|}
\hline \multicolumn{5}{|c|}{ Duration of sensitivity } \\
\hline Valid (years) & Frequency & Percentage & $\begin{array}{l}\text { Valid } \\
\text { percentage }\end{array}$ & $\begin{array}{l}\text { Cumulative } \\
\text { percentage }\end{array}$ \\
\hline $1-2$ & 42 & 38.2 & 38.2 & 38.2 \\
\hline$>2$ & 68 & 61.8 & 61.8 & 100.0 \\
\hline Total & 110 & 100.0 & 100.0 & \\
\hline
\end{tabular}

\begin{tabular}{lllll}
\hline \multicolumn{3}{l}{ Soft drink intake per week } & & \\
\hline Valid & Frequency & Percentage & $\begin{array}{l}\text { Valid } \\
\text { percentage }\end{array}$ & $\begin{array}{l}\text { Cumulative } \\
\text { percentage }\end{array}$ \\
\hline None & 4 & 3.6 & 3.6 & 3.6 \\
Once & 31 & 28.2 & 28.2 & 31.8 \\
Twice & 54 & 49.1 & 49.1 & 80.9 \\
four times & 21 & 19.1 & 19.1 & 100.0 \\
Total & 110 & 100.0 & 100.0 & \\
\hline
\end{tabular}

\begin{tabular}{lllll}
\hline \multicolumn{2}{l}{ Gastric problem } & & & \\
\hline Valid & Frequency (\%) & Percentage & $\begin{array}{l}\text { Valid } \\
\text { percentage }\end{array}$ & $\begin{array}{l}\text { Cumulative } \\
\text { percentage }\end{array}$ \\
\hline Yes & 24 & 21.8 & 21.8 & 21.8 \\
No & 86 & 78.2 & 78.2 & 100.0 \\
Total & 110 & 100.0 & 100.0 & \\
\hline
\end{tabular}

\begin{tabular}{lllll}
\hline \multicolumn{2}{l}{ Gum problem } & & & \\
\hline Valid & Frequency (\%) & Percentage & $\begin{array}{l}\text { Valid } \\
\text { percentage }\end{array}$ & $\begin{array}{l}\text { Cumulative } \\
\text { percentage }\end{array}$ \\
\hline Yes & 12 & 10.9 & 10.9 & 10.9 \\
No & 98 & 89.1 & 89.1 & 100.0 \\
Total & 110 & 100.0 & 100.0 & \\
\hline
\end{tabular}

\begin{tabular}{lllll}
\hline \multicolumn{2}{l}{ Grinding } & & & \\
\hline Valid & Frequency (\%) & Percentage & $\begin{array}{l}\text { Valid } \\
\text { percentage }\end{array}$ & $\begin{array}{l}\text { Cumulative } \\
\text { percentage }\end{array}$ \\
\hline Yes & 5 & & 4.5 & 4.5 \\
No & 105 & 95.5 & 95.5 & 100.0 \\
Total & 110 & 100.0 & 100.0 & \\
\hline
\end{tabular}

\begin{tabular}{|c|c|c|c|c|c|}
\hline \multicolumn{6}{|c|}{ Smoking } \\
\hline Valid & \multicolumn{2}{|c|}{ Frequency (\%) } & Percentage & $\begin{array}{l}\text { Valid } \\
\text { percentage }\end{array}$ & $\begin{array}{l}\text { Cumulative } \\
\text { percentage }\end{array}$ \\
\hline Yes & \multicolumn{2}{|l|}{48} & 43.6 & 43.6 & 43.6 \\
\hline No & \multicolumn{2}{|l|}{62} & 56.4 & 56.4 & \multirow{2}{*}{100.0} \\
\hline Total & \multicolumn{2}{|l|}{110} & 100.0 & 100.0 & \\
\hline \multicolumn{6}{|c|}{ Alcohol consumption } \\
\hline Valid & \multicolumn{2}{|c|}{ Frequency (\%) } & Percentage & $\begin{array}{l}\text { Valid } \\
\text { percentage }\end{array}$ & $\begin{array}{l}\text { Cumulative } \\
\text { percentage }\end{array}$ \\
\hline Yes & \multicolumn{2}{|l|}{32} & 29.1 & 29.1 & \multirow{3}{*}{$\begin{array}{l}29.1 \\
100.0\end{array}$} \\
\hline No & \multirow{2}{*}{\multicolumn{2}{|c|}{$\begin{array}{l}78 \\
110\end{array}$}} & 70.9 & 70.9 & \\
\hline Total & & & 100.0 & 100.0 & \\
\hline \multicolumn{6}{|c|}{ Dental procedures done } \\
\hline Valid & & $\begin{array}{l}\text { Frequency } \\
\text { (\%) }\end{array}$ & Percentage & $\begin{array}{l}\text { Valid } \\
\text { percentage }\end{array}$ & $\begin{array}{l}\text { Cumulative } \\
\text { percentage }\end{array}$ \\
\hline \multicolumn{2}{|c|}{ Scaling } & $14(12.7)$ & 12.7 & 50.0 & 50.0 \\
\hline \multicolumn{2}{|c|}{ Orthodontic } & $10(9.1)$ & 9.1 & 35.7 & 85.7 \\
\hline \multicolumn{2}{|c|}{ RCT } & $4(3.6)$ & 3.6 & 14.3 & 100.0 \\
\hline \multirow{2}{*}{\multicolumn{6}{|c|}{ Missing }} \\
\hline & & & & & \\
\hline \multicolumn{2}{|c|}{ System } & 82 & 74.5 & & \\
\hline \multicolumn{2}{|c|}{ Total } & 110 & 100.0 & & \\
\hline
\end{tabular}

\section{DISCUSSION}

From the data, it was evident that almost half of students were affected by dentine hypersensitivity who responded to the questionnaire. It was found that males were found to be more prone to TS when compared females. The major stimulus for sensitivity was cold [7,12-14]. In the case of the food having sensitive temperatures, people often wait for the food to come to normal temperature which may lead to social discomfort in the presence of other people. It was also found that medium bristles toothbrushes were found to be more in use, and the force of brushing was found to be vigorous in nature which may lead to many gum problems such as gum bleeding and gum recession which may expose the underlying dentin [15]. Hard brushing may also lead to enamel erosion which also exposes the dentin [16]. Unorthodox tooth brushing such as using hard brushes, excessive forces, excessive scrubbing at the cervical areas or even lack of brushing would lead to accumulation of plaque and gingival recession $[17,18]$. It was found that many students were suffering from TS for more than 2 years without any treatment, this may be explained by scientists who have postulated that many patients assume that their condition is a natural occurrence developing with age or that it is untreatable [11]. It was interesting to note that more than half of the students had soft drinks regularly and this may also play a good role in TS due to enamel erosion from bad brushing habits. Erosive agents also play an important role in the progression of TS as they tend to remove or erode the enamel or open up the dentinal tubules, thereby exposing them $[19,20]$. It was also found almost $80 \%$ of the students brush their teeth only once per day. Few students who had sensitivity from dental procedures showed the scaling procedure to be one of the main causes of TS [21]. Gum problems and gastric problems along with grinding of teeth were found to be low among the students which are in relevance with another study made before [22]. Smoking was found in less than half of the students while alcohol consumption was very low.

\section{CONCLUSION}

From the data, one can infer that TS has become quite prevalent in today's society and with less awareness on its treatment. The people should be taught to maintain their oral hygiene, and proper brushing techniques should be taught and diet should be altered according to health. Soft drinks should be avoided to the highest extent and treatment for sensitivity should be taken promptly. 


\section{REFERENCES}

1. Addy M, Mostafa P, Absi EG, Adams D. Cervical dentine hypersensitivity: Aetiology and management with particular reference to dentifrices. In: Rowe NH, editor. Proceedings of Symposium on Hypersensitive Dentine. Origin and Management. Edinburgh and London: The University of Michigan, E and S Livingstone Limited; 1985. p. 4-64.

2. Fischer C, Fischer RG, Wennberg A. Prevalence and distribution of cervical dentine hypersensitivity in a population in Rio de Janeiro, Brazil. J Dent 1992;20(5):272-6.

3. Chabanski MB, Gillam DG, Bulman JS, Newman HN. Prevalence of cervical dentine sensitivity in a population of patients referred to a specialist periodontology department. J Clin Periodontol 1996;23(11):989-92.

4. Bamise CT, Olusile AO, Oginni AO, Dosumu OO. Prevalence of dentine hypersensitivity among adult patients attending a Nigerian teaching hospital. Oral Health Prev Dent 2007;5:49-53.

5. Canadian Advisory Board on Dentin Hypersensitivity. Consensusbased recommendations for the diagnosis and management of dentin hypersensitivity. J Canadian Dent Assoc 2003;69(4):221-6.

6. Bissada NF. Symptomatology and clinical features of hypersensitive teeth. Arch Oral Biol 1994;39 Suppl:31S-32.

7. Orchardson R, Collins WJ. Clinical features of hypersensitive teeth. $\mathrm{Br}$ Dent J 1987;162(7):253-6.

8. Flynn J, Galloway R, Orchardson R. The incidence of 'hypersensitive' teeth in the West of Scotland. J Dent 1985;13(3):230-6.

9. Addy M. Etiology and clinical implications of dentine hypersensitivity. Dent Clin North Am 1990;34(3):503-14

10. Azodo CC, Amayo AC. Dentinal sensitivity among a selected group of young adults in Nigeria. Niger Med J 2011;52(3):189-92.

11. Kielbassa A. Dentine hypersensitivity: Simple steps for everyday diagnosis and management. Int Dent J 2002;52:386-96.

12. Rees JS, Jin LJ, Lam S, Kudanowska I, Vowles R. The prevalence of dentine hypersensitivity in a hospital clinic population in Hong Kong. J Dent 2003;31(7):453-61.

13. Taani SD, Awartani F. Clinical evaluation of cervical dentin sensitivity in patients attending general dental clinics and periodontal specialty clinics J Clin Periodontol 2002;29:118-22.

14. Liu HC, Lan WH, Hsieh CC. Prevalence and distribution of cervical dentin hypersensitivity in a population in Taipei, Taiwan. J Endod 1998;24(1):45-7.

15. Dababneh RH, Khouri AT, Addy M. Dentine hypersensitivity - An enigma? A review of terminology, mechanisms, aetiology and management. Br Dent J 1999;187(11):606-11.

16. Addy M, Mostafa P, Newcombe RG. Dentine hypersensitivity: The distribution of recession, sensitivity and plaque. J Dent 1987;15(6):242-8.

17. Drisko $\mathrm{CH}$. Dentine hypersensitivity - Dental hygiene and periodontal considerations. Int Dent J 2002;52:385-93.

18. Suge T, Kawasaki A, Ishikawa K, Matsuo T, Ebisu S. Effects of plaque control on the patency of dentinal tubules: An in vivo study in beagle dogs. J Periodontol 2006;77(3):454-9.

19. Eisenburger M, Addy M. Erosion and attrition of human enamel in vitro part I: Interaction effects. J Dent 2002;30(7-8):341-7.

20. Osborne-Smith KL, Burke FJ, Wilson NH. The aetiology of the noncarious cervical lesion. Int Dent J 1999;49(3):139-43.

21. von Troil B, Needleman I, Sanz M. A systematic review of the prevalence of root sensitivity following periodontal therapy. J Clin Periodontol 2002;29 Suppl 3:173-7.

22. Bamise CT, Kolawole KA, Oloyede EO, Esan TA. Tooth sensitivity experience among residential university students. Int J Dent Hyg 2010;8(2):95-100. 